\title{
FRACTIONAL ORDER DIFFERENTIAL INCLUSIONS ON AN UNBOUNDED DOMAIN WITH INFINITE DELAY
}

\author{
MOHAMED HELAL
}

\begin{abstract}
In this paper, we provide sufficient conditions for the existence of solutions to initial value problems, for partial hyperbolic differential inclusions of fractional order involving Caputo fractional derivative with infinite delay by applying the nonlinear alternative of Frigon type for multivalued admissible contraction in Fréchet spaces.
\end{abstract}

MSC 2010. 26A33, 34K30, 34K37, 35R 11.

Key words. Partial functional differential inclusion, fractional order, solution, left-sided mixed Riemann-Liouville integral, Caputo fractional-order derivative, infinite delay, Fréchet space, fixed point.

\section{REFERENCES}

[1] R.P. Agarwal, M. Belmekki and M. Benchohra, A survey on semilinear differential equations and inclusions involving Riemann-Liouville fractional derivative, Adv. Difference. Equ., 2009, Article 981728, 1-47.

[2] R.P Agarwal, M. Benchohra and S. Hamani, A survey on existence result for boundary value problems of nonlinear fractional differential equations and inclusions, Acta Appl. Math., 109 (2010), 973-1033.

[3] A. Arara, M. Benchohra, N. Hamidi and J.J. Nieto, Fractional order differential equations on an unbounded domain, Nonlinear Anal., 72 (2010), 580-586.

[4] J.P. Aubin and A. Cellina, Differential Inclusions, Springer-Verlag, Berlin-Heidelberg, New York, 1984.

[5] J.P. Aubin and H. Frankowska, Set-Valued Analysis, Birkhäuser, Boston, 1990.

[6] A. Belarbi, M. Benchohra and A. Ouahab, Uniqueness results for fractional functional differential equations with infinite delay in Fréchet spaces, Appl. Anal., 85 (2006), 14591470.

[7] M. Benchohra, L. Górniewicz, S.K. Ntouyas and A. Ouahab, Controllability results for impulsive functional differential inclusions, Rep. Math. Phys. 54 (2004), 211-227.

[8] M. Benchohra and M. Hellal, Perturbed partial functional fractional order differential equations with Infinite delay, Journal of Advanced Research in Dynamical and Control System, 5 (2013), 1-15.

[9] M. Benchohra and M. Hellal, Perturbed partial fractional order functional differential equations with Infinite delay in Fréchet spaces, Nonlinear Dyn. Syst. Theory, 14 (2014), $244-257$.

The author is grateful to the referees for their helpful comments and suggestions.

DOI: $10.24193 /$ mathcluj.2020.2.06 
[10] M. Benchohra and M. Hellal, A global uniqueness result for fractional partial hyperbolic differential equations with state-dependent delay, Ann. Polon. Math., 110 (2014), 259281.

[11] T. Czlapinski, Existence of solutions of the Darboux problem for partial differentialfunctional equations with infinite delay in a Banach space, Comment. Math. Prace Mat., 35 (1995), 111-122.

[12] T. Czlapinski, On the Darboux problem for partial differential-functional equations with infinite delay at derivatives, Nonlinear Anal., 44 (2001), 389-398.

[13] K. Deimling Multivalued Differential Equations, Walter de Gruyter, Berlin-New York, 1992.

[14] M. Frigon, Fixed Point Results for Multivalued Contractions on Gauge Spaces, in Set Valued Mappings with Applications in Nonlinear Analysis, Ser. Math. Anal. Appl., Vol. 4, Taylor and Francis, London, 2002, 175-181.

[15] M. Frigon and A. Granas, Résultats de type Leray-Schauder pour des contractions sur des espaces de Fréchet, Ann. Math. Qué., 22 (1998), 161-168.

[16] L. Gorniewicz, Topological Fixed Point Theory of Multivalued Mappings, Mathematics and its Applications, Vol. 495, Kluwer Academic Publishers, Dordrecht, 1999.

[17] J. Hale and J. Kato, Phase space for retarded equationswith infinite delay, Funkcial. Ekvac., 21 (1978), 11-41.

[18] J.K. Hale and S. Verduyn Lunel, Introduction to Functional-Differential Equations, Appl. Math. Sci., Vol. 99, Springer-Verlag, New York, 1993.

[19] M. Helal, Fractional Partial Hyperbolic Differential Inclusions with State-Dependent Delay, J. Fract. Calc. Appl., 10 (2019), 179-196.

[20] D. Henry, Geometric Theory of Semilinear Parabolic Partial Differential Equations, Springer-Verlag, Berlin-New York, 1989.

[21] R. Hilfer, Applications of Fractional Calculus in Physics, World Scientific, Singapore, 2000.

[22] Y. Hino, S. Murakami and T. Naito, Functional Differential Equations with Infinite Delay, Lecture Notes in Mathematics, Vol. 1473, Springer-Verlag, Berlin, 1991.

[23] Sh. Hu and N. Papageorgiou, Handbook of Multivalued Analysis, Theory, I, Kluwer, Dordrecht, 1997.

[24] A.A. Kilbas, H.M. Srivastava and J.J. Trujillo, Theory and Applications of Fractional Differential Equations, North-Holland Mathematics Studies, Vol. 204, Elsevier Science B.V., Amsterdam, 2006.

[25] A.A. Kilbas and S.A. Marzan, Nonlinear differential equations with the Caputo fractional derivative in the space of continuously differentiable functions, Differ. Equ., 41 (2005), $84-89$.

[26] M. Kisielewicz, Differential Inclusions and Optimal Control, Kluwer, Dordrecht, 1991.

[27] V. Kolmanovskii, and A. Myshkis, Introduction to the Theory and Applications of Functional-Differential Equations, Kluwer Academic Publishers, Dordrecht, 1999.

[28] V. Lakshmikantham, L. Wen and B. Zhang, Theory of Differential Equations with Unbounded Delay, Kluwer Academic Publishers, Dordrecht, 1994.

[29] K.S. Miller and B. Ross, An Introduction to the Fractional Calculus and Differential Equations, John Wiley, New York, 1993.

[30] S.G. Samko, A.A. Kilbas and O.I. Marichev, Fractional Integrals and Derivatives. Theory and Applications, Gordon and Breach, Yverdon, 1993.

[31] A.N. Vityuk, Existence of Solutions of partial differential inclusions of fractional order, Izv. Vyssh. Uchebn. Zaved. Mat., 8 (1997), 13-19.

[32] A.N. Vityuk and A.V. Golushkov, Existence of solutions of systems of partial differential equations of fractional order, Nonlinear Oscillations, 7 (2004), 318-325. 
Received August 1, 2019

Accepted October 16, 2019
Mustapha Stambouli University of Mascara Science and Technology Faculty

Djillali Liabes University of Sidi Bel-Abbès Laboratory of Mathematics

Algeria

E-mail: helalmohamed@univ-mascara.dz 